\title{
PREFERENCES OF PATIENTS FOR DISCUSSING SUDDEN UNEXPECTED DEATH IN EPILEPSY
}

\author{
Normunds Sūna ${ }^{1,2, \#}$, Evija Gūtmane ${ }^{3}$, Madara Lazdāne ${ }^{3}$, Guntis Karelis ${ }^{1,3}$, \\ and Valdis Folkmanis ${ }^{2}$ \\ ${ }^{1}$ Department of Neurology and Neurosurgery, Riga East Clinical University Hospital “Gaiḷezers", 2 Hipokrāta Str., Riga, LV-1039, LATVIA \\ ${ }^{2}$ University of Latvia, 19 Raina Blvd., Riga, LV-1586, LATVIA \\ ${ }^{3}$ Riga Stradinš University, 16 Dzirciema Str., Riga, LV-1007, LATVIA \\ \# Corresponding author, n.suuna@gmail.com
}

Communicated by Aivars Lejnieks

\begin{abstract}
People with epilepsy have increased mortality rates, which is partially attributed to sudden unexpected death in epilepsy syndrome (SUDEP). Poor seizure control appears to be the strongest SUDEP risk factor. Management of epilepsy and adherence to therapy is critical to seizure control. The belief by caregivers of negative influence caused by being informed about the syndrome is the main reason SUDEP is not disclosed. There are no clear recommendations when to disclose the risk of SUDEP and how much information should be provided. We addressed the preferences of Latvian epilepsy patients for discussing SUDEP as well as awareness of the syndrome. Our study involved 55 epilepsy patients. We found that, as in other studies, our patients were relatively well informed about SUDEP. We found that a considerable proportion of patients preferred to receive information about SUDEP from a general practitioner. We note the belief of patients that the disclosure of SUDEP would either improve or have no effect on the quality of life. We were able to identify groups of patients with a self-reported belief of more frequent expected anxiety and poor adherence to medical treatment. Our data improves the understanding of preferences of patient for discussing the negative aspects of epilepsy.
\end{abstract}

Key words: epilepsy, SUDEP, awareness.

\section{INTRODUCTION}

People with epilepsy have a mortality rate 2-3 times higher than that of the general population (Tomson, 2000). Higher mortality is related to the underlying disorder causing epilepsy or to death as a direct consequence of seizures (accidents, status epilepticus, and sudden unexpected death) (Mohanraj et al., 2006). Sudden unexpected death in epilepsy (SUDEP) is defined as the sudden, unexpected, witnessed or unwitnessed, non-traumatic and non-drowning death of a person with epilepsy with or without a seizure, excluding documented status epilepticus, and in whom post-mortem examination does not reveal a structural or toxicological cause of death (Nashef, 1997). Incidence of SUDEP varies among studies from 0.35 to 2.3 cases per 1000 patient-years in community-based populations to 6.3 to 9.3 cases per 1000 patient-years in epilepsy surgery candidates with refractory seizures (Tomson et al., 2008). Risk of sudden death in epilepsy patients is more than 20 times greater than that in the general population (Ficker et al., 1998). Exact pathophysiology of SUDEP is currently unknown, although generalised tonic-clonic seizure-induced cardiac, respiratory, and brainstem dysfunction appears likely (Maguire et al., 2016). Poor control and a high frequency of primary or secondary generalised tonic-clonic seizures (GTCs) appears to be the strongest SUDEP risk factor (Langan et al., 2005; Hesdorffer et al., 2011).

Preventative strategies for SUDEP include reducing the occurrence of generalised tonic-clonic seizures with optimal medical management and patient education, and timely referral for epilepsy surgery (Sperling et al., 2005; Ryvlin et al., 2011; Ryvlin et al., 2013), and there is limited lowquality evidence of a preventative effect for nocturnal supervision against SUDEP (Maguire et al., 2016). Self- and family-management of epilepsy is critical to seizure control. Therefore, patients and families should be informed about SUDEP and the importance of seizure control in potentially preventing SUDEP (Miller et al., 2014), since poor adherence may be the most important cause of poorly controlled epilepsy, with estimated non-adherence ranging from 30\% to 50\% (Leppik, 1990). Published guidelines and position statements from professional organisations recommend routine counselling on SUDEP, to provide patients with tai- 
lored information about the syndrome, to discuss the patient's individual SUDEP risk and measures to reduce this risk. The timing of a SUDEP discussion and the relative emphasis placed on SUDEP are determined by the presence of risk factors and the physician's awareness of the patient's preparedness to receive the information (So et al., 2009, Anonymous, 2012).

In contrast to the findings of surveys analysing SUDEPdiscussion practices in the UK (Morton et al., 2006), Italy (Vegni et al., 2011), the USA and Canada (Friedman et al., $2014)$, where only a small percentage of respondents $(7.5 \%$, $7.7 \%$, and $11.6 \%$, respectively) never discuss SUDEP with their patients, we previously reported that only $21 \%$ of Latvian neurologists inform their patients about the risk of SUDEP (Suna et al., 2015). The main reason not to disclose SUDEP is the caregivers' belief that being informed about the syndrome might cause permanent anxiety or might have a negative influence on the quality of life by causing fundamental lifestyle changes in epilepsy patients (Beran et al., 2004; Vegni et al., 2011; Suna et al., 2015). Contrary to expectations of physicians, studies in epilepsy patients indicate initial anxiety after being informed about SUDEP, rather than a long-standing negative impact after disclosure (Harden et al., 2015; Tonberg et al., 2015; Xu et al., 2015; Ramachandran Nair and Jack, 2016).

While guidelines recommend to discuss SUDEP with patients and family members, there are no clear recommendations as to when to disclose the risk of SUDEP and what amount of information should be provided. A survey conducted in Australia involving 105 epilepsy patients showed that only $14.3 \%$ of patients were aware of SUDEP, while $89.5 \%$ expressed their willingness to be informed about the syndrome, with the majority of patients $(62.9 \%)$ willing to learn all information pertaining to their medical condition. $85.6 \%$ of patients preferred to receive the information from their neurologist, and a significant proportion of respondents $(42.6 \%)$ wanted to receive this information during the first consultation, and $33.6 \%$ in subsequent visits. SUDEP awareness and willingness to be informed was not associated with age, gender, level of education, occupation, and duration of epilepsy (Xu et al., 2015).

A study from Scotland involving 27 patients showed similar results: only $7.4 \%$ of respondents would prefer not to be informed about the risk of SUDEP. Most patients thought that disclosure should happen at the time of diagnosis of epilepsy $(36 \%)$ or soon after $(64 \%)$. Being informed about SUDEP would change the way patients manage their epilepsy in $37 \%$ of respondents and improve medication adherence in 26\% of respondents (Tonberg et al., 2015).

A Canadian study involving 23 patients with epilepsy showed that $56.5 \%$ of patients preferred to be told about SUDEP at the time of diagnosing epilepsy and $82.6 \%$ believed that the information had to be disclosed by a neurologist. All study participants agreed that both the individuals diagnosed with epilepsy and their caregivers should be informed about SUDEP. 26\% reported being more adherent to medication or controlling their disease since learning about SUDEP (Ramachandran Nair and Jack, 2016).

The aim of our study was to address the preferences of Latvian epilepsy patients for discussing SUDEP, as well as awareness of the syndrome and to compare the results with those of other studies (Tonberg et al., 2015; Xu et al., 2015; Ramachandran Nair and Jack, 2016).

\section{MATERIALS AND METHODS}

A descriptive cross-sectional study design was used to assess SUDEP awareness and preferences for discussing SUDEP. Adult epilepsy patients were recruited between April 2016 and January 2017 to participate in a survey at an outpatient clinic and the Neurology Department of Riga East Clinical University Hospital Gailezers.

The inclusion criteria were as follows: adults aged 18 or older at the time of recruitment, having a confirmed diagnosis of epilepsy, and able to give informed consent. Upon consenting to the study, participants were asked to complete a questionnaire which contained demographic data part and 24-point survey (Table 1). The questionnaire was modified from an Australian study (Xu et al., 2015) together with our original questions which incorporated the level of education, employment status, duration of epilepsy, self-rated level of knowledge about SUDEP and epilepsy, preferences for being informed about SUDEP, psychological aspects, and lifestyle changes caused by SUDEP disclosure. The data were statistically analysed using the IBM SPSS (Version 22) software package (IBM Corporation, New York, USA).

Descriptive statistics included frequencies for categorical variables (shown in absolute numbers and percentages) and mean/median, and standard deviation for numerical variables. An assessment of the normality of data was done by the Shapiro-Wilk test and the Kolmogorov-Smirnov test. The Pearson's chi-square test was used to test for significant relationships between variables among patients (age, gender, level of education, type of epilepsy, duration of epilepsy, occupation) and (a) awareness of SUDEP, and (b) psychological aspects and lifestyle changes caused by SUDEP disclosure, and (c) preferences for being informed about SUDEP.

The study was approved by the Medical and Biomedical Research Ethics Committee of the Riga East Clinical University Hospital.

\section{RESULTS}

Demographics. The study involved 55 epilepsy patients, 23 females and 32 males, with ages ranging from 20 to 87 years (mean $=44.3 \pm 15.0$ ). Primary school education was reported by $18.2 \%(\mathrm{n}=10)$, secondary school education by $40.0 \%(n=22)$, secondary professional education (technical professional education) by $21.8 \%(\mathrm{n}=12)$, and university 
STUDY QUESTIONNAIRE (total $\mathrm{n}=55$ )

\begin{tabular}{|c|c|c|c|c|}
\hline & Question & Response & $\mathrm{n}$ & $\%$ \\
\hline 1 & Employment status & $\begin{array}{c}\text { Employed } \\
\text { Unemployed } \\
\text { Retired } \\
\end{array}$ & $\begin{array}{c}22 \\
29 \\
4\end{array}$ & $\begin{array}{c}40.0 \\
52.7 \\
7.3 \\
\end{array}$ \\
\hline 2 & Level of education & $\begin{array}{l}\text { Primary school education } \\
\text { Secondary school } \\
\text { education } \\
\text { Secondary professional } \\
\text { education } \\
\text { University education }\end{array}$ & $\begin{array}{l}10 \\
22 \\
12 \\
11 \\
\end{array}$ & $\begin{array}{l}18.2 \\
40.0 \\
21.8 \\
20.0\end{array}$ \\
\hline 3 & Duration of epilepsy (years) & $\begin{array}{c}<1 \\
1-5 \\
6-10 \\
11-20 \\
>20 \\
\end{array}$ & $\begin{array}{c}10 \\
14 \\
7 \\
13 \\
11\end{array}$ & $\begin{array}{l}18.2 \\
25.5 \\
12.7 \\
23.6 \\
20.0\end{array}$ \\
\hline \multirow[t]{4}{*}{4} & \multirow{4}{*}{$\begin{array}{l}\text { How would you character- } \\
\text { ise the effectiveness of your } \\
\text { seizure control? }\end{array}$} & Have no more seizures & 16 & 29.1 \\
\hline & & $\begin{array}{l}\text { Seizures are } \\
\text { well-controlled, I seldom } \\
\text { have seizures }\end{array}$ & 26 & 47.3 \\
\hline & & $\begin{array}{l}\text { Seizures are not } \\
\text { well-controlled, I have } \\
\text { frequent seizures, drugs are } \\
\text { partially effective }\end{array}$ & 12 & 21.8 \\
\hline & & $\begin{array}{l}\text { Treatment has absolutely no } \\
\text { effect }\end{array}$ & 1 & 1.8 \\
\hline \multirow[t]{3}{*}{5} & \multirow{3}{*}{$\begin{array}{l}\text { How much information } \\
\text { regarding epilepsy would } \\
\text { you like to receive }\end{array}$} & $\begin{array}{l}\text { Maximum amount of infor- } \\
\text { mation }\end{array}$ & 32 & 58.2 \\
\hline & & $\begin{array}{l}\text { Reasonable amount of } \\
\text { information }\end{array}$ & 15 & 27.3 \\
\hline & & $\begin{array}{l}\text { Minimal amount of infor- } \\
\text { mation }\end{array}$ & 8 & 14.5 \\
\hline \multirow[t]{4}{*}{6} & \multirow{4}{*}{$\begin{array}{l}\text { Who provides you with } \\
\text { information regarding } \\
\text { epilepsy most often? } \\
\text { (single or multiple } \\
\text { responses) }\end{array}$} & Neurologist & 34 & 61.8 \\
\hline & & General practitioner & 12 & 21.8 \\
\hline & & Media, Internet & 9 & 16.4 \\
\hline & & $\begin{array}{l}\text { Relatives and } \\
\text { acquaintances }\end{array}$ & 8 & 14.5 \\
\hline \multirow[t]{4}{*}{7} & \multirow{4}{*}{$\begin{array}{l}\text { Do you think that doctors } \\
\text { have to inform all patients } \\
\text { regarding negative aspects } \\
\text { of epilepsy (e.g., trauma, } \\
\text { bad prognosis, pregnancy } \\
\text { risks, possible death)? }\end{array}$} & Yes & 44 & 80.0 \\
\hline & & No & 5 & 9.1 \\
\hline & & $\begin{array}{l}\text { Only if a patient wants to be } \\
\text { informed }\end{array}$ & 4 & 7.3 \\
\hline & & $\begin{array}{l}\text { Only if a patient is in a } \\
\text { high-risk group }\end{array}$ & 2 & 3.6 \\
\hline \multirow[t]{4}{*}{8} & \multirow{4}{*}{$\begin{array}{l}\text { Regarding negative aspects } \\
\text { of epilepsy (e.g., trauma, } \\
\text { bad prognosis, pregnancy } \\
\text { risks, possible death), how } \\
\text { much information has your } \\
\text { doctor provided you with? }\end{array}$} & No information & 9 & 16.4 \\
\hline & & $\begin{array}{l}\text { Minimal amount of infor- } \\
\text { mation }\end{array}$ & 12 & 21.8 \\
\hline & & $\begin{array}{l}\text { Insufficient amount of in- } \\
\text { formation }\end{array}$ & 20 & 36.4 \\
\hline & & $\begin{array}{l}\text { Sufficient amount of infor- } \\
\text { mation }\end{array}$ & 14 & 25.5 \\
\hline 9 & $\begin{array}{l}\text { Do you think that epilepsy } \\
\text { patients have a higher risk } \\
\text { of sudden death compared } \\
\text { to people without epilepsy? }\end{array}$ & $\begin{array}{l}\text { Yes } \\
\text { No }\end{array}$ & $\begin{array}{l}41 \\
14\end{array}$ & $\begin{array}{l}74.5 \\
25.5\end{array}$ \\
\hline 10 & $\begin{array}{l}\text { If you had a higher risk of } \\
\text { sudden death, would you } \\
\text { prefer to know the details? }\end{array}$ & $\begin{array}{l}\text { Yes } \\
\text { No }\end{array}$ & $\begin{array}{c}48 \\
7\end{array}$ & $\begin{array}{l}87.3 \\
12.7\end{array}$ \\
\hline 11 & $\begin{array}{l}\text { Have you ever heard of } \\
\text { sudden unexpected death in } \\
\text { epilepsy (SUDEP)? }\end{array}$ & $\begin{array}{l}\text { Yes } \\
\text { No }\end{array}$ & $\begin{array}{l}15 \\
40\end{array}$ & $\begin{array}{l}27.3 \\
72.7\end{array}$ \\
\hline 12 & If your answer is yes, where & Neurologist & 4 & 26.7 \\
\hline & did you get this information & General practitioner & 1 & 6.6 \\
\hline & from? $(\mathrm{n}=15)$ & Media, Internet & 6 & 40.0 \\
\hline & & Relatives and acquaintances & 4 & 26.7 \\
\hline
\end{tabular}

\begin{tabular}{|c|c|c|c|c|}
\hline 13 & $\begin{array}{l}\text { Has your neurologist or } \\
\text { general practitioner dis- } \\
\text { cussed SUDEP with you? }\end{array}$ & $\begin{array}{l}\text { Yes } \\
\text { No }\end{array}$ & $\begin{array}{l}13 \\
42\end{array}$ & $\begin{array}{l}23.6 \\
76.4\end{array}$ \\
\hline \multirow[t]{3}{*}{14} & \multirow{3}{*}{$\begin{array}{l}\text { How much information re- } \\
\text { garding SUDEP would you } \\
\text { like to receive? }\end{array}$} & Detailed information & 13 & 23.6 \\
\hline & & Basic information & 33 & 60.0 \\
\hline & & None & 9 & 16.4 \\
\hline \multirow[t]{5}{*}{15} & \multirow{5}{*}{$\begin{array}{l}\text { Who should provide pa- } \\
\text { tients with information re- } \\
\text { garding SUDEP? } \\
\text { (single or multiple re- } \\
\text { sponses) }\end{array}$} & Neurologist & 35 & 63.6 \\
\hline & & General practitioner & 19 & 34.5 \\
\hline & & $\begin{array}{l}\text { Emergency department doc- } \\
\text { tor }\end{array}$ & 5 & 9.1 \\
\hline & & Media, Internet & 3 & 5.5 \\
\hline & & Relatives and acquaintances & 3 & 5.5 \\
\hline 16 & $\begin{array}{l}\text { Do you think that doctors } \\
\text { have to inform all patients } \\
\text { regarding SUDEP? }\end{array}$ & $\begin{array}{l}\text { Yes } \\
\text { No }\end{array}$ & $\begin{array}{l}45 \\
10\end{array}$ & $\begin{array}{l}81.8 \\
18.2\end{array}$ \\
\hline \multirow[t]{4}{*}{17} & \multirow[t]{4}{*}{$\begin{array}{l}\text { What is the most appropri- } \\
\text { ate moment for a patient to } \\
\text { be informed about SUDEP? }\end{array}$} & $\begin{array}{l}\text { During the } 1^{\text {st }} \text { consultation } \\
\text { after confirmation of epi- } \\
\text { lepsy diagnosis }\end{array}$ & 25 & 45.5 \\
\hline & & During the $2^{\text {nd }}$ consultation & 5 & 9.1 \\
\hline & & $\begin{array}{l}\text { During subsequent consul- } \\
\text { tations }\end{array}$ & 15 & 27.3 \\
\hline & & $\begin{array}{l}\text { Only if the seizure control } \\
\text { worsens }\end{array}$ & 10 & 18.2 \\
\hline 18 & $\begin{array}{l}\text { Do you think SUDEP } \\
\text { awareness could influence } \\
\text { the quality of your life by } \\
\text { causing permanent anxiety? }\end{array}$ & $\begin{array}{l}\text { Yes } \\
\text { No }\end{array}$ & $\begin{array}{l}34 \\
21\end{array}$ & $\begin{array}{l}61.8 \\
38.2\end{array}$ \\
\hline 19 & $\begin{array}{l}\text { Would you reject counsel- } \\
\text { ling on SUDEP, if you be- } \\
\text { lieved that awareness could } \\
\text { cause a strongly negative } \\
\text { impact on the quality of } \\
\text { your life? }\end{array}$ & $\begin{array}{l}\text { Yes } \\
\text { No }\end{array}$ & $\begin{array}{l}21 \\
34\end{array}$ & $\begin{array}{l}38.2 \\
61.8\end{array}$ \\
\hline 20 & $\begin{array}{l}\text { Do you think SUDEP } \\
\text { awareness may have a neg- } \\
\text { ative influence on } \\
\text { the quality of your life } \\
\text { by causing } \\
\text { fundamental lifestyle } \\
\text { changes? }\end{array}$ & $\begin{array}{l}\text { Yes } \\
\text { No }\end{array}$ & $\begin{array}{l}30 \\
25\end{array}$ & $\begin{array}{l}54.5 \\
45.5\end{array}$ \\
\hline \multirow[t]{3}{*}{21} & \multirow{3}{*}{$\begin{array}{l}\text { Which statement would de- } \\
\text { scribe your emotions and } \\
\text { lifestyle change best, if you } \\
\text { were informed about a high } \\
\text { risk of SUDEP? }\end{array}$} & $\begin{array}{l}\text { Quality of life would not } \\
\text { change }\end{array}$ & 22 & 40.0 \\
\hline & & $\begin{array}{l}\text { Quality of life would de- } \\
\text { crease because of anxiety } \\
\text { and insecurity about the fu- } \\
\text { ture. }\end{array}$ & 13 & 23.6 \\
\hline & & $\begin{array}{l}\text { Quality of life would im- } \\
\text { prove, I would live a more } \\
\text { wholesome life }\end{array}$ & 20 & 36.4 \\
\hline 22 & $\begin{array}{l}\text { Would SUDEP awareness } \\
\text { improve your compliance } \\
\text { with treatment? }\end{array}$ & $\begin{array}{l}\text { Yes } \\
\text { No }\end{array}$ & $\begin{array}{l}43 \\
12\end{array}$ & $\begin{array}{l}78.2 \\
21.8\end{array}$ \\
\hline 23 & $\begin{array}{l}\text { Do you believe that SUDEP } \\
\text { is preventable? }\end{array}$ & $\begin{array}{c}\text { Yes } \\
\text { No } \\
\text { I don't know }\end{array}$ & $\begin{array}{l}39 \\
14 \\
2\end{array}$ & $\begin{array}{r}70.9 \\
25.5 \\
3.6 \\
\end{array}$ \\
\hline \multirow[t]{8}{*}{24} & \multirow{8}{*}{$\begin{array}{l}\text { What concerns you the } \\
\text { most in relation to epi- } \\
\text { lepsy? }\end{array}$} & Driving restrictions & 17 & 30.9 \\
\hline & & Work restrictions & 20 & 36.4 \\
\hline & & Lifestyle restrictions & 19 & 34.5 \\
\hline & & Social stigma & 11 & 20.0 \\
\hline & & Side effects of medications & 22 & 40.0 \\
\hline & & Necessity of medication use & 22 & 40.0 \\
\hline & & Risk of seizures & 32 & 58.2 \\
\hline & & $\begin{array}{l}\text { Sudden unexpected death in } \\
\text { epilepsy (SUDEP) }\end{array}$ & 12 & 21.8 \\
\hline
\end{tabular}


education by $20 \%(\mathrm{n}=11)$ of patients. The majority of patients $(60.0 \%)$ were unemployed or retired.

Epilepsy characteristics. The duration of epilepsy was $<1$ year in $18.2 \%(n=10), 1-5$ years in $25.5 \%(n=14), 6-10$ years in $12.7 \%(n=7), 11-20$ years in $23.6 \%(n=11)$ and $>20$ years in $20 \%(n=11)$ of patients (Table 1$)$. The study sample had the following epilepsy characteristics: symptomatic epilepsy in $58.2 \%(\mathrm{n}=32)$, genetic generalised epilepsy in $30.9 \%(n=17)$, and cryptogenic or unclassified epilepsy in $10.9 \%(n=6)$ of respondents. Regarding the frequency of generalised tonic-clonic seizures (GTCs), one patient had daily seizures, $12.7 \%(\mathrm{n}=7)$ had weekly seizures, $27.3 \%(\mathrm{n}=15)$ had GTCs every month, 34.5\% ( $\mathrm{n}=$ 19) had only a few seizures a year, $5.5 \%(\mathrm{n}=3)$ had had $1-5$ seizures during the previous 5 years, and $18.2 \%(\mathrm{n}=$ 10) had had no GTCs during the previous 5 years (other types of seizures were possible in this group). The majority of patients $(76.4 \%, \mathrm{n}=42)$ subjectively rated their epilepsy as well-controlled or were seizure free with antiepileptic drug treatment, while $23.6 \%(n=13)$ had poor seizure control.

Willingness to be informed about epilepsy. A neurologist was the specialist who usually provided information regarding epilepsy in $61.8 \%(\mathrm{n}=34)$ of cases, and a general practitioner in $21.8 \%(n=12)$ of cases, while in $16.4 \%(n=9)$ of cases the source of information was the media and the Internet. The majority of patients $(58.2 \%, \mathrm{n}=32)$ desired to receive the maximum amount of information about epilepsy, $27.3 \%(n=15)$ preferred a reasonable amount of information, and a minority of patients $14.5 \%(n=8)$ wanted to know a minimal amount of information. Regarding the negative aspects of epilepsy, $80 \%(n=44)$ of patients believed that everyone has to be informed, although only one in four patients $(25.5 \%, \mathrm{n}=14)$ reported having received a sufficient amount of such information.

Awareness of SUDEP. Three quarters of respondents $(74.5 \%, \mathrm{n}=41)$ believed that epilepsy has a higher risk of sudden death, while only $27.3 \%(\mathrm{n}=15)$ had previously heard of SUDEP syndrome; however, $87.3 \%(n=48)$ still wanted to be informed of the risk of dying. Of the 15 patients who were aware of SUDEP, an equal number of patients $(26.7 \%, \mathrm{n}=4)$ had obtained the information from a neurologist or from relatives and acquaintances. Social media was a source of information for a surprisingly large percentage of the respondents $(40 \%, \mathrm{n}=6)$. Basic information about SUDEP was the preferred level of knowledge to receive in the majority of patients $(60.0 \%, \mathrm{n}=33)$, but $16 \%$ $(n=9)$ of respondents opted not to know about the syndrome. Epilepsy patients preferred to receive the information about SUDEP from a neurologist or a general practitioner $(62.6 \%$ and $34.5 \%$, respectively), while $81.8 \%(n=49)$ thought that all epilepsy patients had to be informed. Almost one half of respondents $(45.5 \%, \mathrm{n}=25)$ would prefer disclosure of risk of SUDEP during the first epilepsy consultation, while $18.2 \%(n=10)$ would choose not to know about the syndrome until the worsening of seizure control.
Influence of the awareness of SUDEP. Regarding the possible effects of SUDEP awareness, 61.8\% ( $\mathrm{n}=34)$ of patients believed that being informed would cause permanent anxiety, and in $54.5 \%(n=30)$ of patients awareness could produce fundamental lifestyle changes, negatively affecting their quality of life. If patients expected a highly negative impact from being informed about SUDEP, many of them $(38.2 \%, \mathrm{n}=21)$ would refuse counselling. When asked about the possible impact of the awareness of having a high risk of SUDEP on daily life, most patients $(40.0 \%, \mathrm{n}=22)$ believed there would be no impact, and an almost similar percentage of respondents $(36.4 \%, \mathrm{n}=20)$ expected improvement of the quality of life, while only $23.6 \%(n=13)$ reported possible deterioration of the quality of life due to psychological factors. Improvement of compliance after counselling was expected by $78.2 \%(n=43)$ of the patients. When factors causing concern in case of epilepsy were addressed, SUDEP and social stigma were reported as the least worrying issues among the given examples.

Influence of age, gender, education and employment on responses. Male respondents were less aware of SUDEP syndrome than female respondents $(15.6 \%$ vs. $43.5 \%, p=$ 0.032 ). When the issue of the amount of preferred information was addressed, employed patients wanted to receive detailed information about SUDEP more often $(40.9 \%, \mathrm{n}=9)$ than unemployed patients $(12.1 \%, \mathrm{n}=4, p=0.031)$; and there was a tendency in preference of more detailed information in patients with a higher level of education. There was no significant influence of age, gender, and level of education on the willingness to receive detailed information if a respondent had a high risk of sudden death.

After being informed about SUDEP, $12.5 \%(\mathrm{n}=1)$ of respondents in the age group of 18-25-year-olds expected anxiety vs. $81.5 \%(\mathrm{n}=22)$ in the group of $26-50$-year-olds $(p=0.04)$, thus showing a significant difference between these groups. However there was no difference among the age groups regarding expected fundamental lifestyle changes. Among the patients who expected a highly negative influence after being informed about SUDEP, respondents in the age group of $26-50$ had the highest proportion of those refusing counselling $(55.6 \%, n=15 / 27)$. There was a significantly higher proportion of respondents willing to refuse counselling in the group with secondary school education $(63.6 \%, \mathrm{n}=14)$ vs. those in the group with university education $(27.3 \%, \mathrm{n}=3)(p=0.016)$. Negative psychological impact was expected more often by patients in the group with secondary school education $(45.5 \%, \mathrm{n}=10 / 22)$ vs. those $(9.1 \%, \mathrm{n}=1 / 11)$ in the group with university education $(p=0.033)$. Patients with university education expected improved compliance $(100.0 \%, \mathrm{n}=11)$, compared to the group with primary school education $(50.0 \%, \mathrm{n}=5 / 10)(p=$ $0.047)$; the expected compliance was $75.0 \%$ and $81.8 \%$ in the secondary professional education group and the secondary school education group, respectively. SUDEP risk concern was raised in $40.9 \%(n=9)$ of employed patients and $9.1 \%(n=3)$ of unemployed patients $(p=0.008)$. There was no difference between the employed and the unemployed 
group in factors that concern epilepsy patients, such as the probability to have seizures, necessity of medication use, side effects of medications, and work or driving restrictions. The employed respondents had a tendency to be affected by social stigma more often than the unemployed respondents (31.8\% vs. $12.1 \%, p=0.074)$. There was a strong tendency towards statistical significance that work restrictions concerned male respondents more than female respondents ( $46.9 \%$ vs. $21.7 \%, p=0.056)$.

\section{DISCUSSION}

Our patients were informed about the SUDEP syndrome relatively more often $(27.3 \%)$ compared to findings of other studies. Most patients $(40.0 \%)$ obtained this information from the Internet or the media, but only $7.2 \%$ of the participants in our study had received information about SUDEP from a neurologist, which does not contradict the results from the study we had previously conducted, which showed that only a small part of neurologists in Latvia had informed patients about the risk of SUDEP. It has to be emphasised that more than $1 / 3$ of patients would like to receive information about SUDEP from a general practitioner. This underlines the necessity of educational work among general practitioners regarding SUDEP and its risk. These results differ from those obtained in other countries (Xu et al., 2015), where only a small number of patients wanted to receive such information from their general practitioner; this could be explained by different specifics in the organisation of healthcare.

Most of our patients $(61.8 \%)$ noted that being informed would cause permanent anxiety, thereby negatively affecting the quality of life, which corresponds to the previously discussed doctor opinions on the effects of being informed (Beran et al., 2004; Vegni et al., 2011; Suna et al., 2015). However, we know from prospective studies that such anxiety will not continue in the long term (Harden et al., 2015; Tonberg et al., 2015; Xu et al., 2015; Ramachandran Nair and Jack, 2016). Thus our results confirm that patients agree with the assumption of doctors that a pronounced anxiety will be caused by being informed, thereby emphasising the importance of the time and mode of communicating this information, which might very likely be psychotraumatic in nature. It has to be mentioned that, if patients were aware that they themselves have a high risk of SUDEP, most of them would not change their habits; however, the quality of life for $1 / 3$ of patients would be improved by making lifestyle changes and trying to live a more wholesome life. In general, this is why, according to the patients, being informed about SUDEP would have no adverse effect on the quality of life or might even improve it, despite the initial anxiety caused by such a fact. This, in turn, serves as an important argument for informing the patients about SUDEP; however, such correlation has not been prospectively proved.

Although the patients were aware of these psychologically traumatising aspects, most of them $(81.8 \%)$ believed that all patients should be informed about SUDEP. Similarly, most patients $(90.9 \%)$ would not decline being informed about negative aspects of epilepsy. This finding corresponds with results from other studies regarding the willingness of patients to be informed (Tonberg et al., 2015; Xu et al., 2015). In general, $45.5 \%$ of respondents wanted to be informed about SUDEP during the first consultation, while $9.1 \%$ of respondents indicated a preference for the second consultation, and $27.3 \%$ opted for subsequent visits; the obtained results correspond with the conclusions made in other studies, indicating the existing tendency that most patients wish to be informed about SUDEP soon after the establishment of diagnosis (Tonberg et al., 2015; Xu et al., 2015).

Our study reiterates that most patients $(78.2 \%)$ emphasise the fact that SUDEP awareness would improve their compliance with therapy and would encourage a more active monitoring of their state of health. Since there are no other compelling preventive strategies against SUDEP, except effective seizure control, awareness is the preferred way, chosen by patients themselves, to improve seizure control. The belief of patients in improved compliance is about twice as high in our population compared to that described in other studies (Tonberg et al., 2015; Ramachandran Nair and Jack, 2016), leading to consideration of cultural differences. It should be noted that a significant number of patients (38.2\%) who anticipated that being informed about SUDEP might have an extremely negative impact on the quality of life would decline to participate in discussion about SUDEP. Therefore, based on our experience with surveyed patients, we would recommend that it should be clarified whether a patient wishes to know about the negative aspects of epilepsy, including the risk of death, as well as when and to what extent the patient wishes to be informed. This method corresponds to the generally accepted practice regarding other negative information in medicine, that a patient has the right to know and choose the preferred amount of information.

We were able to identify two groups of patients according to their age and level of education (26-50-year-olds, secondary education) who, if they anticipated that awareness might have a decidedly negative effect on the quality of life, would be statistically more likely to experience anxiety after being informed about SUDEP and would be more likely to decline being informed. It should also be noted that all patients with a university education stated a foreseeable improvement of compliance after being informed about SUDEP, while such correlation was observed only in $50 \%$ of patients with primary school education. Such correlation has not been described in other studies, which reiterates the necessity for additional educational efforts in groups with foreseeably low compliance, as well as a more balanced approach to consultation in various groups of differing age and education. However, such correlations should be prospectively studied.

The weaknesses of our study included the lack of prospective follow-up of patients, as well as the lack of information as to whether awareness among our target population would 
cause long-term anxiety. In the same way, although patients maintain that, as a result of SUDEP awareness, compliance would be improved, this assertion has not been prospectively studied and our study does not prove this statement.

\section{REFERENCES}

Anonymous (2012). National Institute of Clinical Excellence. The epilepsies: The diagnosis and management of the epilepsies in adults and children in primary and secondary care (UK). Available at: www.nice.org.uk/guidance/cg137 (accessed 10 January 2017).

Beran, R. G., Weber, S., Sungaran, R., Venn, N., Hung, A. (2004). Review of the legal obligations of the doctor to discuss Sudden Unexplained Death in Epilepsy (SUDEP) - a cohort controlled comparative cross-matched study in an outpatient epilepsy clinic. Seizure, 13 (7), 523-528.

Ficker, D. M., So, E. L., Shen, W. K., Annegers, J. F., O'Brien, P. C., Cascino, G. D., Belau, P. G. (1998). Population-based study of the incidence of sudden unexplained death in epilepsy. Neurology, 51 (5), $1270-1274$.

Friedman, D., Donner, E. J., Stephens, D., Wright, C., Devinsky, O. (2014). Sudden unexpected death in epilepsy: Knowledge and experience among U.S. and Canadian neurologists. Epilepsy Behav., 35,13-18.

Harden, J., Tonberg, A., Chin, R. F., McLellan, A., Duncan, S. (2015). 'If you're gonna die, you're gonna die': Young adults' perceptions of sudden unexpected death in epilepsy. Chronic Illn., 11 (3), 230-241.

Hesdorffer, D. C., Tomson, T., Benn, E., Sander, J. W., Nilsson, L., Langan, Y., Walczak, T. S., Beghi, E., Brodie, M. J., Hauser, A. (2011). Combined analysis of risk factors for SUDEP. Epilepsia, 52 (6), 1150-1159.

Langan, Y., Nashef, L., Sander J. W. (2005). Case-control study of SUDEP. Neurology. 64 (7), 1131-1133.

Leppik, I. E. How to get patients with epilepsy to take their medication. (1990). The problem of noncompliance. Postgrad Med., 88 (1), 253-256.

Maguire, M. J., Jackson, C. F., Marson, A. G., Nolan, S. J. (2016). Treatments for the prevention of Sudden Unexpected Death in Epilepsy (SUDEP). Cochrane Database Syst Rev., 19, 7.

Miller, W. R., Young, N., Friedman, D., Buelow, J. M., Devinsky, O. (2014). Discussing sudden unexpected death in epilepsy (SUDEP) with patients: Practices of health-care providers. Epilepsy Behav., 32, 38-41.
Mohanraj, R., Norrie, J., Stephen, L. J., Kelly, K., Hitiris, N., Brodie, M. J. (2006). Mortality in adults with newly diagnosed and chronic epilepsy: A retrospective study. Lancet Neurol., 5, 481-487.

Morton, B., Richardson, A., Duncan, S. (2006). Sudden unexpected death in epilepsy (SUDEP): Don't ask, don't tell? J. Neurol. Neurosurg. Psychiatry, 77 (2), 199-202.

Nashef, L. (1997). Sudden unexpected death in epilepsy: Terminology and definitions. Epilepsia, 38, 6-8.

Ramachandran Nair, R., Jack, S. M. (2016). SUDEP: What do adult patients want to know? Epilepsy Behav., 64 (Pt A), 195-199.

Ryvlin, P., Cucherat, M., Rheims, S. (2011). Risk of sudden unexpected death in epilepsy in patients given adjunctive antiepileptic treatment for refractory seizures: A meta-analysis of placebo-controlled randomised trials. Lancet Neurol., 10 (11), 961-968.

Ryvlin, P., Nashef, L., Tomson, T. (2013). Prevention of sudden unexpected death in epilepsy: A realistic goal? Epilepsia, 54 Suppl 2, 23-28.

So, E. L., Bainbridge, J., Buchhalter, J. R., Donalty, J., Donner, E. J., Finucane, A., Graves, N. M., Hirsch, L. J., Montouris, G. D., Temkin, N. R., Wiebe, S., Sierzant, T. L. (2009). Report of the American Epilepsy Society and the Epilepsy Foundation joint task force on sudden unexplained death in epilepsy. Epilepsia, 50 (4), 917-922.

Sperling, M. R., Harris, A., Nei, M., Liporace, J. D., O'Connor, M. J. (2005). Mortality after epilepsy surgery. Epilepsia, 46 Suppl 11, 49-53.

Suna, N., Lazdane, M., Karelis, G., Vitols, E. (2015). Awareness of sudden unexpected death in epilepsy among neurologists in Latvia. Proc. Latvian Acad. Sci., Section B, Vol. 69, No. 5.

Tomson, T. (2000). Mortality in epilepsy. J. Neurol., 247 (1), 15-21.

Tomson, T., Nashef, L., Ryvlin, P. (2008). Sudden unexpected death in epilepsy: Current knowledge and future directions. Lancet Neurol., 7 (11), 1021-1031.

Tonberg, A., Harden, J., McLellan, A., Chin, R. F., Duncan, S. (2015). A qualitative study of the reactions of young adults with epilepsy to SUDEP disclosure, perceptions of risks, views on the timing of disclosure, and behavioural change. Epilepsy Behav., 42, 98-106.

Vegni, E., Leone, D., Canevini, M. P., Tinuper, P., Moja, E. A. (2011). Sudden unexpected death in epilepsy (SUDEP): A pilot study on truth telling among Italian epileptologists. Neurol Sci., 32 (2), 331-335.

Xu, Z., Ayyappan, S., Seneviratne, U. (2015). Sudden unexpected death in epilepsy (SUDEP): What do patients think? Epilepsy Behav., 42, 29-34.

Received 2 March 2017

Accepted in the final form 11 March 2017

\section{PACIENTU VĒLMES, TIEKOT INFORMĒTIEM PAR PĒKŠṆAS NEGAIDĪTAS NĀVES EPILEPSIJAS LAIKĀ SINDROMU}

Pacientiem ar epilepsiju ir palielināta mirstība, kas daḷēji saistīta ar pēkšṇas negaidītas nāves epilepsijas laikā sindromu (SUDEP). Slikta lēkmju kontrole tiek uzskatīta par nozīmīgāko SUDEP riska faktoru. Epilepsijas aprūpe un līdzestība terapijai ir ļoti nozīmīga lēkmju kontroles nodrošināšanai. Aprūpes sniedzēju viedoklis, ka informētībai ir negatīva ietekme, ir galvenais iemesls, kāpēc diskusija par sindromu ir nepiln̄̄ga. Nav precīzu rekomendāciju par to, kad pacients būtu jāinformē par SUDEP un kāds ir sniedzamās informācijas apjoms. Mēs izpētījām Latvijas epilepsijas pacientu vēlmes, diskutējot par SUDEP, kā arī informētību par šo sindromu. Tika atklāts, ka nozīmīga pacientu dạa vēlas saṇemt informāciju par SUDEP no ğimenes ārsta. Mēs uzsveram pacientu uzskatu, ka informētība par SUDEP vai nu uzlabotu dzīves kvalitāti, vai arī neatstātu uz to ietekmi. Tika identificētas pacientu grupas, kas ziṇoja par sagaidāmu biežāku trauksmi pēc informēšanas un paredzamu sliktāku līdzestību. Pētījuma dati uzlabo izpratni par pacientu vēlmēm, diskutējot par SUDEP un citiem negatīviem epilepsijas aspektiem. 